\title{
Genetic Variability of Rotylenchulus reniformis
}

Megan Leach and Paula Agudelo, Department of Entomology, Soils, and Plant Sciences, Clemson University, Clemson, SC 29634; and Amy Lawton-Rauh, Department of Genetics and Biochemistry, Clemson University, Clemson, SC 29634

\begin{abstract}
Leach, M., Agudelo, P., and Lawton-Rauh, A. 2012. Genetic variability of Rotylenchulus reniformis. Plant Dis. 96:30-36.

Rotylenchulus reniformis, reniform nematode, is a polyphagous pest commonly found parasitizing cotton in the southeastern United States. We developed and optimized 10 polymorphic microsatellite loci found in reniform nematode and tested them on 160 individual reniform nematodes to determine informative genetic variation of isolates from the southeastern United States, Colombia, Japan, and from the species Rotylenchulus parvus. No significant gametic disequilibrium was detected between any pair of loci, and most loci were not in expected Hardy-Weinberg proportions. A positive $\mathrm{F}_{\mathrm{IS}}$ coefficient was observed at all 10 loci, suggesting a high level of inbreeding at these loci. Most isolate locations exhibited significant genotypic differentiation and moderate to very high genetic differentiation based on $\mathrm{F}_{\mathrm{ST}}$ analysis.

The most consistently differentiated isolates were found reproducing parthenogenetically in Japan. These isolates were also found to represent the most basal locality in this study based on unweighted pair group method with arithmetic mean (UPGMA) clustering analysis and were distinct from other localities based on STRUCTURE V 2.3 analysis. These results support previous reports suggesting that the parthenogenetically reproducing isolates from Japan are another species. Taken together, our results can serve as the foundation for more extensive characterization of population structure and genetic variation among isolates of $R$. reniformis variants to help discern the impact of alternative processes on genetic connectivity and differentiation in the genetically undercharacterized reniform nematode.
\end{abstract}

Rotylenchulus reniformis (reniform nematode) is a plant-parasitic nematode commonly associated with a large number of cultivated plants in subtropical, tropical, and temperate soils worldwide $(15,24,34)$. In the United States, reniform nematode has become one of the major pests in Upland cotton (Gossypium hirsutum) production. Lint yield and quality can be significantly reduced due to reniform nematode infection (10). In 2009, an estimated 203,720 bales of cotton were lost due to reniform nematode in the United States (7). The highest losses occurred in Alabama, Louisiana, and Mississippi. Reniform nematode also caused greater loss than rootknot nematode in Alabama, Louisiana, Mississippi, and Tennessee. Cotton crop specialists have reported an increase in the distribution and prevalence of reniform nematode over the last decade, especially in the southeastern cotton-growing region (31). In 2010, reniform nematode was found parasitizing cotton across the Southeast, from Texas to Virginia. Resistance to reniform nematode has not been found naturally occurring in Upland cotton $(33,39)$. Efforts to introgress resistance from cotton relatives, such as Gossypium longicalyx (32), are in progress, but there are currently no commercially available cotton cultivars with resistance to reniform nematode.

Reniform nematode has been described as a highly variable species. Morphological differences have been reported for isolates around the world, including populations from Japan (24), Brazil (35), and Africa (16). Morphological differences have also been described among isolates from the southern cotton-growing region (1). Differences in embryonic development were reported among isolates from cotton fields in Alabama, Mississippi, and South Carolina (20). One study in Japan found differences in the reproductive compatibility of isolates, reporting one isolate that reproduced strictly parthenogenetically (24). The genetic variability of this species has been understudied. Agudelo et al. (1) found no polymorphisms in the ITS1 region among amphimictically reproducing individuals from the United States, Brazil, Colombia, Hon-

Corresponding author: Paula Agudelo, E-mail: pagudel@clemson.edu

Accepted for publication 1 August 2011.

http://dx.doi.org/10.1094/PDIS-02-11-0132

(C) 2012 The American Phytopathological Society duras, and Japan. Only the parthenogenetic isolate from Japan was distinct. In 2009, Arias et al. (4) found genetic variability at 88 microsatellite loci from reniform nematode populations from four southern states (Texas, Louisiana, Mississippi, and Georgia) using DNA pooled from 1,000 to 2,000 eggs, but the study did not look at genetic variation of individuals.

Currently there is no standardized method for characterizing phenotypic or genetic variants of $R$. reniformis. The development of effective management strategies is directly related to the ecological significance of the phenotypic variation in $R$. reniformis and the correlation of such variation with genetic diversity in the nematode. The identification of intraspecific variation will have practical significance to control nematodes or reduce damage to crops through the use of resistant varieties and nonhost plants.

Microsatellites are highly polymorphic, codominant markers that can be useful in characterizing plant pathogens due to the fast rate of mutation accumulation and an informative substitution stepwise mutation model. Development of microsatellite markers to study individual nematode genomic DNA can allow for genetic comparison of individuals from populations throughout the cottongrowing regions of the United States. Polymorphic microsatellite loci markers enable investigation of population subdivision, gene flow, parentage, and relatedness. The development of microsatellite markers for plant parasitic nematodes is often limited by low DNA recovery from individual nematodes. Glenn and Schable (17) recommend using 2 to $3 \mu \mathrm{g}$ of high quality DNA to begin microsatellite marker development. Thousands of nematodes are required to achieve this amount of DNA. Here we use Whole Genome Amplification (WGA) to develop microsatellite markers in reniform nematode. The objective of this research was to use polymorphic microsatellite markers to study the genetic variability of individual reniform nematodes from the southeastern cotton-growing region.

\section{Materials and Methods}

Microsatellite development. Reniform nematodes were obtained from infested field soil from Calhoun County, SC and maintained in a greenhouse on cotton. DNA was extracted from 10 vermiform $R$. reniformis using $25 \mu$ of Worm Lysis Buffer $(\mathrm{KCl} 50$ $\mathrm{mM}$, Tris $10 \mathrm{mM}, \mathrm{pH} 8.3$, Tween $200.45 \%$, Triton $\mathrm{X} 0.45 \%$, Proteinase $\mathrm{K} 60 \mu \mathrm{g} / \mathrm{ml}, \mathrm{MgCl}_{2} 2.5 \mathrm{~m}, \mathrm{dH}_{2} \mathrm{O}$ ). The nematodes were placed directly into the buffer in a $1.5-\mathrm{ml}$ centrifuge tube and incubated at $-80^{\circ} \mathrm{C}$ for $10 \mathrm{~min}$. The nematodes were crushed with a 
pestle and then incubated at $65^{\circ} \mathrm{C}$ for $1 \mathrm{~h}$, vortexing several times during incubation to help break up the tissue. A subsequent incubation at $95^{\circ} \mathrm{C}$ for $15 \mathrm{~min}$ was used to inactivate the Proteinase $\mathrm{K}$, followed by cooling to $4^{\circ} \mathrm{C}$. We used $1 \mu \mathrm{l}$ of the extracted DNA for WGA by multiple displacement using GE Healthcare's GenomiPhi V2 kit following the manufacturer's protocol. Microsatellite DNA loci were then isolated following the general procedure established by Glenn and Schable (17) and the specific methodology described in Leach et al. (21).

Microsatellite analysis of individuals. Ten individual vermiform females of $R$. reniformis from each of 15 locations and 10 individual vermiform females of $R$. parvus were included in this study. Isolation locations in the United States included Alabama, Arkansas, Florida, Georgia, Louisiana, Mississippi, North Carolina, South Carolina, and Texas (Table 1). Individual vermiform females from Colombia and Japan were also included in the study to determine genetic variability of isolates within the United States compared to other countries. Two populations from Japan were included: one known to reproduce amphimictically (JA) and one known to reproduce parthenogenetically (JP).

Whole cell content DNA was extracted from 160 individual reniform nematodes using Sigma Extract-N-Amp kit (XNAT2). To

Table 1. Table of Rotylenchulus isolates including species, isolation location, host crop, and abbreviation used to refer to isolation locations

\begin{tabular}{llll}
\hline Species & Location & Host & Abbrev. \\
\hline R. reniformis & Alabama & Soybean & AL \\
R. reniformis & Arkansas & Soybean & AR \\
R. reniformis & Colombia & Banana & CB \\
R. reniformis & Colombia & Tobacco & CT \\
R. reniformis & Florida & Dracaena spp. & FL \\
R. reniformis & Georgia & Cotton & GA \\
R. reniformis & Japan Amphimictic & Sweet Potato & JA \\
R. reniformis & Japan Parthenogenetic & Sweet Potato & JP \\
R. reniformis & Louisiana & Cotton & LAC \\
R. reniformis & Louisiana & Soybean & LAS \\
R. reniformis & Mississippi & Soybean & MS \\
R. reniformis & North Carolina & Soybean & NC \\
R. reniformis & South Carolina & Cotton & SC \\
R. reniformis & Texas Field & Cotton & TXF \\
R. reniformis & Texas Greenhouse & Cotton & TX \\
R. parvus & Arizona & Bentgrass & RP \\
\hline
\end{tabular}

extract DNA from individuals, the manufacturer's protocol was modified by reducing all volumes to one-eighth of the recommended amounts. One nematode was placed into a 0.2-ml centrifuge tube containing $12.5 \mu \mathrm{l}$ of Extraction Solution. The nematode was then crushed using the tip of a $<10 \mu \mathrm{l}$ pipette tip. Subsequently, $3.5 \mu \mathrm{l}$ of Tissue Prep solution was added to the tube. The tube was then mixed and centrifuged briefly to collect contents. Tubes were then incubated at $65^{\circ} \mathrm{C}$ for $10 \mathrm{~min}$ followed by $95^{\circ} \mathrm{C}$ for $3 \mathrm{~min}$. Next, $12.5 \mu \mathrm{l}$ of Neutralization Solution B was added to each tube, mixed, and centrifuged briefly. Extracted DNA was then stored at $4^{\circ} \mathrm{C}$.

DNA from each individual was amplified at 10 polymorphic microsatellite loci. Optimized annealing temperature was determined for each microsatellite primer pair using an MJ Research PTC-100 thermocycler (Table 2). Cycling conditions were as follows: $94^{\circ} \mathrm{C}$ for $3 \mathrm{~min}$ followed by 35 cycles at $94^{\circ} \mathrm{C}$ for $30 \mathrm{~s}$, optimum primer annealing temperature for $30 \mathrm{~s}, 72^{\circ} \mathrm{C}$ for $1 \mathrm{~min}$, and a final extension at $72^{\circ} \mathrm{C}$ for $10 \mathrm{~min}$. Each $20-\mu \mathrm{l}$ polymerase chain reaction (PCR) contained $2 \mu \mathrm{l}$ of DNA and $18 \mu \mathrm{l}$ of PCR mix $(1.25 \times$ PCR Buffer, $0.25 \mathrm{mM}$ dNTPs, $2.5 \mathrm{mM} \mathrm{MgCl}_{2}, 0.5 \mu \mathrm{M}$ forward primer, $0.5 \mu \mathrm{M}$ reverse primer, and $0.125 \mathrm{U}$ Taq). All forward primers were labeled with fluorescent dye FAM (Invitrogen). Amplicons were detected using an ABI 3730xl DNA Analyzer with GeneScan 500 ROX used as the size standard (Applied Biosystems). Peak data were analyzed using Peak Scanner software version 1.0 (Applied Biosystems) and allele calls were visually inspected.

Data analysis. The Excel Microsatellite Toolkit (28) was used to determine polymorphism information content, number of alleles per locus, and observed and expected heterozygosities. GenePop V 4.0 (37) was used to test for linkage between loci, deviations from expected Hardy-Weinberg proportions, distribution of genotypes, and Rho statistics. Arlequin V 3.5 (14) was used to analyze $F$ statistics between subpopulations and within a subpopulation. Population structure was assessed using STRUCTURE V 2.3, which uses a Bayesian approach to infer the most likely number of populations (K) present (18). STRUCTURE Tools For Population Genetic Analyses (TFPGA) V 1.3 (23) was used for cluster analysis based on unbiased distance between subpopulations.

\section{Results}

For the 160 individual reniform nematodes at the 10 microsatellite loci, total alleles per locus ranged from 10 to 24 (Table 2).

Table 2. Primer sequences and characteristics of 10 polymorphic microsatellite loci amplified in 160 Rotylenchulus individuals from various hosts and isolation locations ${ }^{\mathrm{a}}$

\begin{tabular}{|c|c|c|c|c|c|c|c|c|c|}
\hline Locus & Repeat motif & Primer sequence $\left(5^{\prime} \rightarrow 3^{\prime}\right)$ & $T_{\mathrm{a}}\left({ }^{\circ} \mathbf{C}\right)$ & $k$ & $\boldsymbol{H}_{\mathrm{e}}$ & $H_{\mathbf{o}}$ & PIC & $\mathbf{F}_{\text {IS }}$ & GB \\
\hline RR1-5 & $(\mathrm{ga})_{7},(\mathrm{ga})_{7},(\mathrm{ga})_{7},(\mathrm{ga})_{7}$ & $\begin{array}{l}\text { F:TGCGAGAGAGAGAGAGAGTGA } \\
\text { R:TGGTGTTAATGGTGAAAGCG }\end{array}$ & 62 & 24 & 0.835 & 0.380 & 0.817 & 0.5291 & HQ158019 \\
\hline RR2-5 & $(\mathrm{cact})_{3}$ & $\begin{array}{l}\text { F:GGGCACTGAAAACACCAAGA } \\
\text { R:TGAGTGGACACAATCCGAAA }\end{array}$ & 60 & 11 & 0.505 & 0.069 & 0.436 & 0.8165 & HQ158020 \\
\hline RR2-6 & $(\text { catt })_{4}$ & $\begin{array}{l}\text { F:GAATGAATTGGCAAAATGGC } \\
\text { R:CTCCATGGCTTTCTCCTCAG }\end{array}$ & 62 & 12 & 0.653 & 0.569 & 0.593 & 0.0797 & HQ158021 \\
\hline RR3-3 & $(\text { catt })_{3},(\text { attc })_{3}$ & $\begin{array}{l}\text { F:AATGGGCGTCTAGTTCCCTT } \\
\text { R:ATCGAAAATGACATGCACCA }\end{array}$ & 60 & 17 & 0.879 & 0.369 & 0.865 & 0.6524 & HQ158013 \\
\hline RR3-8 & $(\mathrm{ga})_{10},(\mathrm{ag})_{5},(\mathrm{ag})_{5}$ & $\begin{array}{l}\text { F:TTGCTTTACTTCCGCTTCGT } \\
\text { R:GCTCCATTTTTCCCACTCAA }\end{array}$ & 61 & 22 & 0.801 & 0.474 & 0.775 & 0.3000 & HQ158015 \\
\hline RR4-1 & $(\operatorname{ttga})_{4}$ & $\begin{array}{l}\text { F:AGAAAATGCTTTTCCCGAGG } \\
\text { R:AGAATTAGCGTTTGGGGATG }\end{array}$ & 63 & 17 & 0.674 & 0.233 & 0.651 & 0.5019 & HQ158016 \\
\hline RR4-4 & $(\operatorname{ttga})_{4}$ & $\begin{array}{l}\text { F:GAAAATGCTTTTCCCGAGGT } \\
\text { R:CGGTAGAATTAGCGTTTGGG }\end{array}$ & 63 & 10 & 0.540 & 0.215 & 0.506 & 0.4422 & HQ158017 \\
\hline RR4-5 & $(\operatorname{tggg})_{3}$ & $\begin{array}{l}\text { F:TGTAATGACCCGAGTGTGGA } \\
\text { R:GGGTCTCCCGGTAGTACGAT }\end{array}$ & 57 & 13 & 0.722 & 0.290 & 0.700 & 0.6573 & HQ158018 \\
\hline RR5 & $(\mathrm{ttg})_{4}$ & $\begin{array}{l}\text { F:CTCCGCCATTACCATTCTGT } \\
\text { R:CCCCAATTCCAACAACAATC }\end{array}$ & 54 & 23 & 0.911 & 0.228 & 0.900 & 0.8299 & GU471239 \\
\hline RR2 & $(\operatorname{tggg})_{3}$ & $\begin{array}{l}\text { F:AAAGATGCCAAAAGAATGCG } \\
\text { R:GATATGCGTTGGCTGTGTTG }\end{array}$ & 58 & 13 & 0.233 & 0.086 & 0.229 & 0.5616 & GU471236 \\
\hline
\end{tabular}

${ }^{a} T_{\mathrm{a}}$ is the polymerase chain reaction annealing temperature; $k$ is the number of alleles observed at each locus; $H_{\mathrm{e}}$ and $H_{\mathrm{o}}$ are expected and observed heterozygosities, respectively; PIC is polymorphic information content at each locus; $\mathrm{F}_{\mathrm{IS}}$ is the inbreeding coefficient; and GB is the GenBank accession number. 
Expected and observed heterozygosities ranged from 0.233 to 0.911 and from 0.069 to 0.569 , respectively. Polymorphism information content (PIC) ranged from 0.229 to 0.900 . PIC (8) is an index of how informative a genetic marker can be by taking into account the number of alleles and their frequencies and is measured by the probability that a parent is heterozygous multiplied by the probability that the offspring is informative. Loci were not restricted to amplification in $R$. reniformis but were also amplified in $R$. parvus.

From GenePop V 4.0 (37), no significant linkage disequilibrium was found among any pairs of loci $(P$ value 0.01$)$ using Fisher's method. At the 0.01 significance level, only one locus (RR2-6) was found to be in expected Hardy-Weinberg proportions for all 160 isolates when using a null hypothesis that assumes random union of gametes with the alternative hypothesis being a deficiency of heterozygotes. Genotypes were not found to be drawn from the same distribution in all populations across all 10 loci and were considered significantly different ( $P$ value 0.01 ) (Table 3$)$. The distribution of diploid genotypes in populations was tested with the null hypothesis "genotypes are drawn from the same distribution in all populations" (GenePop V 4.0 option 3, suboption 4) (37), and results were based on contingency tables. The rejection zone was defined as the sum of the probabilities of all tables having a loglikelihood ratio $(G)$ higher than or equal to the observed $G$ value. Analysis was performed for all pairs of samples across all loci. Based on individual genotypic differentiation, the Japan parthenogenetic (JP) isolate was found to be significantly differentiated from all other isolation locations $(P$ value 0.01$)$. The Louisiana isolate from soybean (LAS) was statistically differentiated from all other isolates, except from the other isolate from Louisiana found parasitizing cotton (LAC). This was also observed for the isolate parasitizing tobacco from Colombia (CT), which was differentiated from other isolates except the other isolate from Colombia parasitizing banana $(\mathrm{CB})$. This suggests that geographic origin has a greater effect than host on isolate differentiation. R. parvus was not significantly differentiated from all isolation locations.

Table 3. Genotypic differentiation between isolation locations $(P=0.01)$ based on genotype distributions ${ }^{\mathrm{a}}$

\begin{tabular}{|c|c|c|c|c|c|c|c|c|c|c|c|c|c|c|c|c|}
\hline & $\mathbf{A L}$ & AR & CB & CT & FL & GA & JA & JP & LAC & LAS & MS & NC & SC & TXF & TX & $\mathbf{R P}$ \\
\hline AL & - & & & $*$ & & & $*$ & $*$ & & $*$ & & $*$ & & $*$ & $*$ & $*$ \\
\hline AR & & - & $*$ & $*$ & $*$ & $*$ & $*$ & $*$ & $*$ & $*$ & $*$ & $*$ & & $*$ & $*$ & $*$ \\
\hline $\mathrm{CB}$ & & & - & & & $*$ & & $*$ & $*$ & $*$ & $*$ & $*$ & & $*$ & $*$ & $*$ \\
\hline $\mathrm{CT}$ & & & & - & $*$ & $*$ & $*$ & $*$ & $*$ & $*$ & $*$ & $*$ & $*$ & $*$ & $*$ & $*$ \\
\hline FL & & & & & - & & $*$ & $*$ & & $*$ & $*$ & & & $*$ & & \\
\hline GA & & & & & & - & & $*$ & & $*$ & & & & $*$ & & \\
\hline JA & & & & & & & - & $*$ & & $*$ & $*$ & $*$ & $*$ & & $*$ & $*$ \\
\hline JP & & & & & & & & - & $*$ & $*$ & $*$ & $*$ & $*$ & $*$ & $*$ & $*$ \\
\hline LAC & & & & & & & & & - & & & & $*$ & $*$ & & \\
\hline LAS & & & & & & & & & & - & $*$ & $*$ & $*$ & $*$ & $*$ & $*$ \\
\hline MS & & & & & & & & & & & - & & & $*$ & $*$ & $*$ \\
\hline $\mathrm{NC}$ & & & & & & & & & & & & - & $*$ & $*$ & $*$ & \\
\hline $\mathrm{SC}$ & & & & & & & & & & & & & - & $*$ & & $*$ \\
\hline TXF & & & & & & & & & & & & & & - & $*$ & $*$ \\
\hline $\mathrm{TX}$ & & & & & & & & & & & & & & & - & \\
\hline $\mathrm{RP}$ & & & & & & & & & & & & & & & & - \\
\hline
\end{tabular}

a * Indicates a significant result and rejects the null hypothesis "genotypes are drawn from the same distribution in all populations".

Table 4. Pairwise $\mathrm{F}_{\mathrm{ST}}$ between isolation localities of Rotylenchulus reniformis and one R. parvus isolate ${ }^{\mathrm{a}}$

\begin{tabular}{|c|c|c|c|c|c|c|c|c|c|c|c|c|c|c|c|}
\hline & $\mathbf{A R}$ & CB & CT & FL & GA & JA & JP & LAC & LAS & MS & NC & SC & TXF & TX & $\mathbf{R P}$ \\
\hline $\mathrm{AL}$ & 0.017 & $\begin{array}{l}0.072 \\
*\end{array}$ & $\begin{array}{l}0.175 \\
* *\end{array}$ & $\begin{array}{l}0.071 \\
*\end{array}$ & 0.024 & $\begin{array}{l}0.118 \\
*\end{array}$ & $\begin{array}{l}0.226 \\
* *\end{array}$ & $\begin{array}{l}0.050 \\
*\end{array}$ & $\begin{array}{l}0.160 \\
* *\end{array}$ & $\begin{array}{l}0.088 \\
*\end{array}$ & $\begin{array}{l}0.116 \\
*\end{array}$ & 0.040 & $\begin{array}{l}0.187 \\
* *\end{array}$ & $\begin{array}{l}0.124 \\
*\end{array}$ & $\begin{array}{l}0.097 \\
*\end{array}$ \\
\hline AR & - & $\begin{array}{l}0.134 \\
*\end{array}$ & $\begin{array}{l}0.230 \\
* *\end{array}$ & $\begin{array}{l}0.081 \\
*\end{array}$ & $\begin{array}{l}0.070 \\
*\end{array}$ & $\begin{array}{l}0.168 \\
* *\end{array}$ & $\begin{array}{l}0.265 \\
* * *\end{array}$ & $\begin{array}{l}0.061 \\
*\end{array}$ & $\begin{array}{l}0.143 \\
*\end{array}$ & $\begin{array}{l}0.105 \\
*\end{array}$ & $\begin{array}{l}0.125 \\
*\end{array}$ & $\begin{array}{l}0.054 \\
*\end{array}$ & $\begin{array}{l}0.200 \\
* *\end{array}$ & $\begin{array}{l}0.096 \\
*\end{array}$ & $\begin{array}{l}0.096 \\
*\end{array}$ \\
\hline CB & & - & 0.044 & $\begin{array}{l}0.090 \\
*\end{array}$ & $\begin{array}{l}0.075 \\
*\end{array}$ & $\begin{array}{l}0.060 \\
*\end{array}$ & $\begin{array}{l}0.168 \\
* *\end{array}$ & $\begin{array}{l}0.102 \\
*\end{array}$ & $\begin{array}{l}0.196 \\
* *\end{array}$ & $\begin{array}{l}0.183 \\
* *\end{array}$ & $\begin{array}{l}0.152 \\
* *\end{array}$ & $\begin{array}{l}0.096 \\
*\end{array}$ & $\begin{array}{l}0.152 \\
* *\end{array}$ & $\begin{array}{l}0.169 \\
* *\end{array}$ & $\begin{array}{l}0.158 \\
* *\end{array}$ \\
\hline $\mathrm{CT}$ & & & - & $\begin{array}{l}0.218 \\
* *\end{array}$ & $\begin{array}{l}0.133 \\
*\end{array}$ & $\begin{array}{l}0.070 \\
*\end{array}$ & $\begin{array}{l}0.202 \\
* *\end{array}$ & $\begin{array}{l}0.171 \\
* *\end{array}$ & $\begin{array}{l}0.262 \\
* * *\end{array}$ & $\begin{array}{l}0.263 \\
* * *\end{array}$ & $\begin{array}{l}0.247 \\
* *\end{array}$ & $\begin{array}{l}0.210 \\
* *\end{array}$ & $\begin{array}{l}0.179 \\
* *\end{array}$ & $\begin{array}{l}0.256 \\
* * *\end{array}$ & $\begin{array}{l}0.252 \\
* * *\end{array}$ \\
\hline FL & & & & - & $\begin{array}{l}0.088 \\
*\end{array}$ & $\begin{array}{l}0.173 \\
* *\end{array}$ & $\begin{array}{l}0.241 \\
* *\end{array}$ & $\begin{array}{l}0.059 \\
*\end{array}$ & $\begin{array}{l}0.193 \\
* *\end{array}$ & $\begin{array}{l}0.138 \\
*\end{array}$ & $\begin{array}{l}0.097 \\
*\end{array}$ & $\begin{array}{l}0.081 \\
*\end{array}$ & $\begin{array}{l}0.190 \\
* *\end{array}$ & $\begin{array}{l}0.085 \\
*\end{array}$ & $\begin{array}{l}0.098 \\
*\end{array}$ \\
\hline GA & & & & & - & 0.042 & $\begin{array}{l}0.165 \\
* *\end{array}$ & 0.048 & $\begin{array}{l}0.125 \\
*\end{array}$ & $\begin{array}{l}0.053 \\
*\end{array}$ & $\begin{array}{l}0.062 \\
*\end{array}$ & $\begin{array}{l}0.057 \\
*\end{array}$ & $\begin{array}{l}0.097 \\
*\end{array}$ & $\begin{array}{l}0.094 \\
*\end{array}$ & $\begin{array}{l}0.050 \\
*\end{array}$ \\
\hline JA & & & & & & - & $\begin{array}{l}0.123 \\
*\end{array}$ & $\begin{array}{l}0.089 \\
*\end{array}$ & $\begin{array}{l}0.170 \\
* *\end{array}$ & $\begin{array}{l}0.201 \\
* *\end{array}$ & $\begin{array}{l}0.143 \\
*\end{array}$ & $\begin{array}{l}0.168 \\
* *\end{array}$ & $\begin{array}{l}0.060 \\
*\end{array}$ & $\begin{array}{l}0.190 \\
* *\end{array}$ & $\begin{array}{l}0.179 \\
* *\end{array}$ \\
\hline JP & & & & & & & - & $\begin{array}{l}0.190 \\
* *\end{array}$ & $\begin{array}{l}0.270 \\
* * *\end{array}$ & $\begin{array}{l}0.284 \\
* * *\end{array}$ & $\begin{array}{l}0.196 \\
* *\end{array}$ & $\begin{array}{l}0.275 \\
* * *\end{array}$ & $\begin{array}{l}0.192 \\
* *\end{array}$ & $\begin{array}{l}0.254 \\
* * *\end{array}$ & $\begin{array}{l}0.236 \\
* *\end{array}$ \\
\hline LAC & & & & & & & & - & 0.041 & $\begin{array}{l}0.098 \\
*\end{array}$ & $\begin{array}{l}0.097 \\
*\end{array}$ & $\begin{array}{l}0.073 \\
*\end{array}$ & $\begin{array}{l}0.136 \\
*\end{array}$ & $\begin{array}{l}0.076 \\
*\end{array}$ & $\begin{array}{l}0.068 \\
*\end{array}$ \\
\hline LAS & & & & & & & & & - & $\begin{array}{l}0.164 \\
* *\end{array}$ & $\begin{array}{l}0.161 \\
* *\end{array}$ & $\begin{array}{l}0.129 \\
*\end{array}$ & $\begin{array}{l}0.149 \\
*\end{array}$ & $\begin{array}{l}0.098 \\
*\end{array}$ & $\begin{array}{l}0.127 \\
*\end{array}$ \\
\hline MS & & & & & & & & & & - & $\begin{array}{l}0.090 \\
*\end{array}$ & 0.044 & $\begin{array}{l}0.208 \\
* *\end{array}$ & $\begin{array}{l}0.111 \\
*\end{array}$ & $\begin{array}{l}0.094 \\
*\end{array}$ \\
\hline $\mathrm{NC}$ & & & & & & & & & & & - & $\begin{array}{l}0.098 \\
*\end{array}$ & $\begin{array}{l}0.118 \\
*\end{array}$ & $\begin{array}{l}0.074 \\
*\end{array}$ & 0.040 \\
\hline $\mathrm{SC}$ & & & & & & & & & & & & - & $\begin{array}{l}0.176 \\
* *\end{array}$ & $\begin{array}{l}0.061 \\
*\end{array}$ & $\begin{array}{l}0.073 \\
*\end{array}$ \\
\hline TXF & & & & & & & & & & & & & - & $\begin{array}{l}0.159 \\
* *\end{array}$ & $\begin{array}{l}0.144 \\
*\end{array}$ \\
\hline TX & & & & & & & & & & & & & & - & 0.045 \\
\hline
\end{tabular}

a * Indicates moderate genetic differentiation, $0.05-0.15 ; * *$ indicated high differentiation, $0.15-0.25 ; * * *$ indicates very high differentiation, $>0.25$. 
Deficiencies of heterozygotes lead to a departure from expected Hardy-Weinberg genotype proportions. Therefore, analysis of Wright's $F$ statistics was used to determine deviation in heterozygosity using Arlequin V 3.5 (14). Results showed a mean $\mathrm{F}_{\mathrm{IS}}=$ $0.54087, \mathrm{~F}_{\mathrm{ST}}=0.12935, \mathrm{~F}_{\mathrm{IT}}=0.60026$, indicating that most of the deficiency in heterozygotes was a result of individuals relative to subpopulations and total population rather than a result of the subpopulation relative to the total population. A relative high value for $\mathrm{F}_{\text {IS }}$ indicated high inbreeding within subpopulations. Subpopulations also showed a moderate genetic differentiation among populations based on $\mathrm{F}_{\mathrm{ST}}$ analysis. According to Nei (26), $\mathrm{F}_{\mathrm{ST}}$ values between 0.05 and 0.15 indicate moderate genetic differentiation, values between 0.15 and 0.25 indicate a great differentiation, and values above 0.25 indicate a very great differentiation. No $F_{S T}$ values were found to be negative. Pairwise $F_{S T}$ values (Table 4) indicated that all isolates were a minimum of greatly differentiated genetically from JP and exhibit a high proportion of genetic diversity from allele frequency differences among the populations relative to JP. R. parvus (RP) was only moderately genetically differentiated from most isolates except North Carolina (NC) and Texas (TX). Based on allele frequency differences, NC and TX did not exhibit genetic differentiation from RP due to subdivision. Georgia (GA) and LAC showed the least amount of differentiation from other isolation locations excluding JP.

Rho statistics were calculated using GenePop V 4.0 (37) which are based on allele sizes and not number of repeats. These measures are analogous to Wright's $F$ statistics and showed a similar result to $F$ statistical analysis. The overall analysis resulted in a mean $\rho_{\mathrm{IS}}=0.7439, \rho_{\mathrm{ST}}=0.2095, \rho_{\mathrm{IT}}=0.7975$. A relatively high value for $\rho_{\mathrm{IT}}$ across loci also indicated an excess in homozygotes that is usually related to a high inbreeding effect between individuals within isolation locations. The fixation index of differentiation between populations division $\left(\rho_{\mathrm{ST}}\right)$ shows that most of the variation is due to genetic differences within isolation locations $(80 \%)$ rather than between isolation locations $(20 \%)$.

TFPGA (23) was used to determine genetic distances between isolation locations and to illustrate a dendrogram of isolate clustering. All unweighted pair group method with arithmetic mean (UPGMA) clustering algorithms placed the Japan parthenogenetic population as the basal population $100 \%$ of the time at all 10 loci. Other nodes did not have a high bootstrap support value. Nei's 1972 minimum distance measure was used for all subsequent UPGMA cluster analyses because zero trees produced from bootstrap sampling contained ties and proportion of similar replicates was higher per node when compared with other distance measures. One node contained what was considered a significant bootstrap value (above 80\%) which separated JP from all other isolation locations (Fig. 1). The genetic distance was calculated to be 0.2267 . UPGMA clustering failed to parse out RP from other isolation locations, indicating that the species is still closely related to R. reniformis.

A no admixture model with correlated allele frequencies was used in STUCTURE V 2.3 (18) with a 100,000 burn-in period followed by 500,000 MCMC iterations. The model was chosen as the best fit due to a small $\alpha$ value $(<0.09)$ being returned when running data under an admixture model. The manual suggests that if a small $\alpha$ value (near zero) is calculated using an admixture model, then most individuals have little admixture. Our results returned $\alpha$ values 0.04 to 0.06 when $\mathrm{K}$ was varied from 2 to 20 . A likelihood ratio test was used to determine whether a model with allele frequencies correlated or independent was the best fit. From the likelihood ratio test, a correlated allele frequency was found to be the best fit model. The value of $\mathrm{K}$ was varied from 2 to 20 . The value with the highest $\log$ likelihood value was $K=14(\operatorname{Ln} P(D)=$

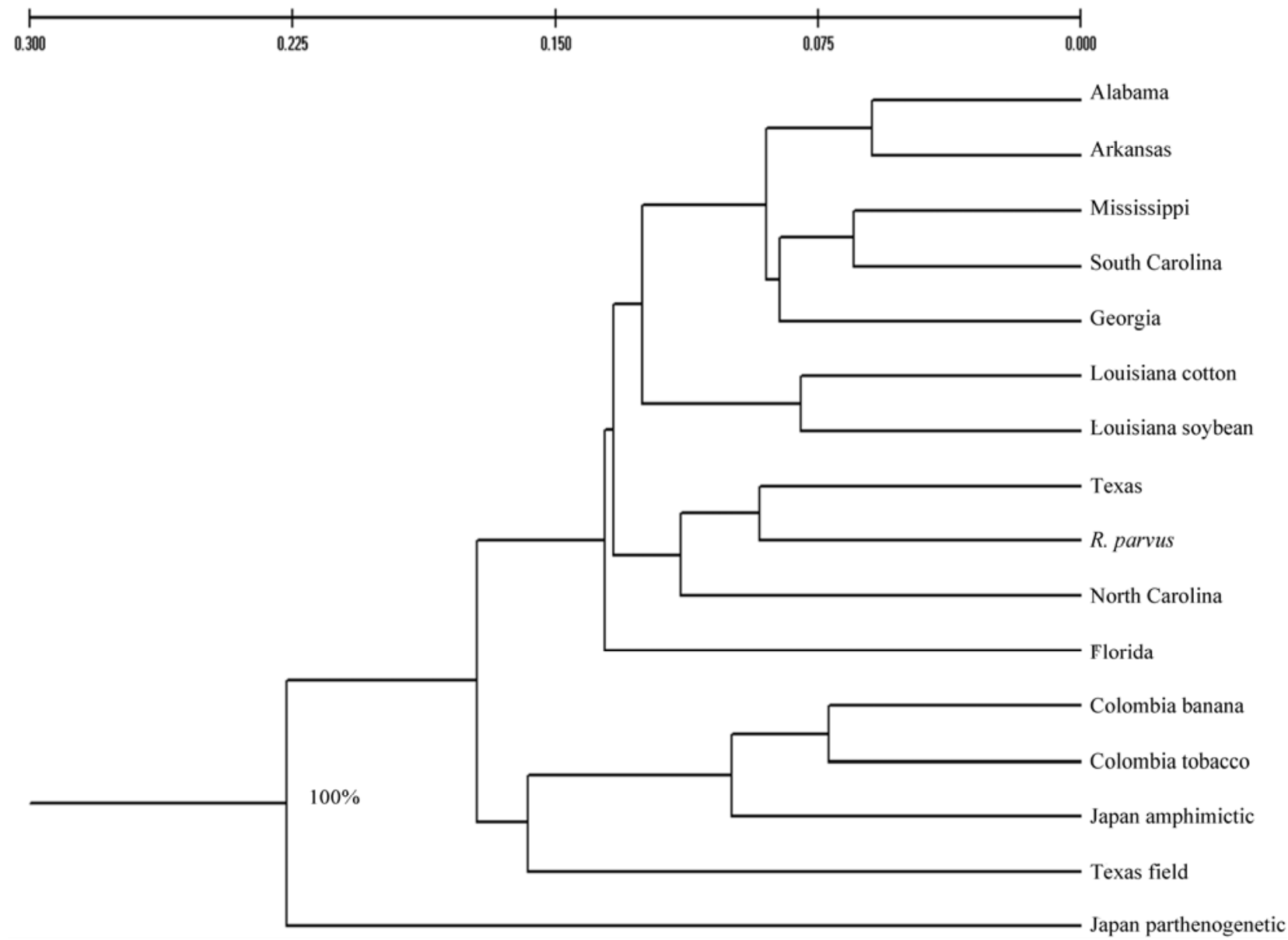

Fig. 1. Unweighted pair group method with arithmetic mean (UPGMA) dendrogram of Rotylenchulus isolates from 10 microsatellite loci constructed using Nei's (1972) minimum distance measure of genetic diversity. Numerical values of nodes with bootstrap values of less than $80 \%$ are not shown as they were not considered significant. 
-3433.72). Analysis did not reveal a distinct cluster of isolates based on isolation (Fig. 2). Only the individuals isolated from Japan that reproduced parthenogenetically were parsed out as a distinct isolation location. Again, $R$. parvus was not found to be a distinct group of individuals, but alleles present in the haplotypes were also observed in haplotypes from $R$. reniformis isolates. JP had the highest distinct Bayesian cluster $(94.1 \%)$ compared with other isolation locations. The only other location that had above $5 \%$ clustering with JP's distinct cluster were isolates from GA, with $12.5 \%$ homogeneity to the JP isolate. The isolates from GA exhibited less than $17 \%$ homogeneity to any of the 14 clusters, suggesting that the isolates from GA have maintained many alleles that can still be found in other isolation locations. The next highest cluster was assigned to CT (85.5\%), with the third highest being LAS with $72.4 \%$ homogeneity. TXF was the only other isolation location to exhibit above $50 \%(52.7 \%)$ homogeneity of isolates based on cluster analysis.

\section{Discussion}

Glenn and Schable (17) discuss the advantages and disadvantages to mixing DNA from multiple individuals when isolating microsatellite DNA loci. In order to avoid the use of markers from any one individual, which may create an ascertainment bias, we decided to use DNA from 10 individuals. However, the DNA extracted from 10 reniform females was not enough for the construction of genomic DNA libraries enriched for microsatellite loci. The amount of individuals that would have been required for the desired quality and quantity of DNA would have introduced a different set of problems. Whole genome amplification, an increasingly common technique through which minute amounts of DNA can be multiplied to generate quantities suitable for genetic analysis (17), offered a good solution to the problem. We chose to use multiple displacement amplification, and specifically the Genomi-Phi kit, which has been found to generate the least amount of bias among the commonly commercially available protocols for WGA (30).

Reniform nematode populations appear to be able to maintain a high level of genetic diversity at 10 microsatellite loci. This high level of genetic diversity did not allow a correlation of haplotype to isolation location. The only distinct isolation location was the Japan parthenogenetic (JP) population, supporting the case for reinstating $R$. nicotiana as a valid species. This parthenogenetically reproducing reniform nematode from Japan was originally described as Tetylenchus nicotiana (40), was later moved to the genus
Rotylenchulus by Baker (5), and then was redescribed as R. nicotiana by Nakasono and Ichinohe (25). In 1968, Dasgupta et al. (11) synonymized $T$. nicotiana ( $R$. nicotiana) with $R$. reniformis, along with four other species ( $R$. elisensis, $R$. queirozi, $R$. leiperi, and $R$. stakmani). Nakasono (24) published physiological and ecological studies that proved the reproductive isolation between the malenumerous $(R$. reniformis) and the male-absent $(R$. nicotiana) isolates from Japan. His findings are well supported by Agudelo et al. (1), who found $11.78 \%$ divergence in ITS1 sequences between parthenogenetic reniform from Japan and 20 other amphimictically reproducing populations of $R$. reniformis. Our findings are congruous with these two previous works and further support the validity of $R$. nicotiana as a separate species. Based on TFPGA and STRUCTURE population grouping analysis, JP was more distant genetically from $R$. reniformis isolates than $R$. parvus at 10 microsatellite loci studied. Greater genetic distance can cause a lower percentage of loci to amplify between species (19), but all 10 loci were amplified in both $R$. reniformis and $R$. parvus, suggesting that both species are very closely related. STRUCTURE analysis revealed that many isolates share alleles, but there is not a distinct haplotype that correlates with isolation location or host. More alleles appear to be shared between amphimictically reproducing $R$. reniformis isolates and $R$. parvus than are shared with JP. The alleles present in $R$. parvus were not found in all isolation locations but may represent the presence of ancestral alleles. Our data suggest that it is possible that $R$. parvus and $R$. reniformis constitute the same species, but further evidence is required (i.e., more isolates, other molecular markers, confirmation of reproductive isolation, etc.) before we recommend that they are synonymized.

A previous microsatellite study of reniform nematode populations (4) used DNA pooled from 1,000 to 2,000 eggs rather than DNA extracted from individuals. Due to high intraspecific variation among individuals within sampling locations, pooled nematode DNA is not a suitable method for characterizing variation. Arias et al. (4) found differences between isolates from four southern cotton-growing states: Texas, Louisiana, Mississippi, and Georgia. Because there was high variation among individuals from one sampling location, pooled DNA may not show the true amount of variation present from one sampling location. Based on $F$ statistics, deficiency of heterozygotes was a result of the individual and not the subpopulation.

Isolates from Texas showed subdivision and genetic differentiation between individuals cultured in a greenhouse versus individu-

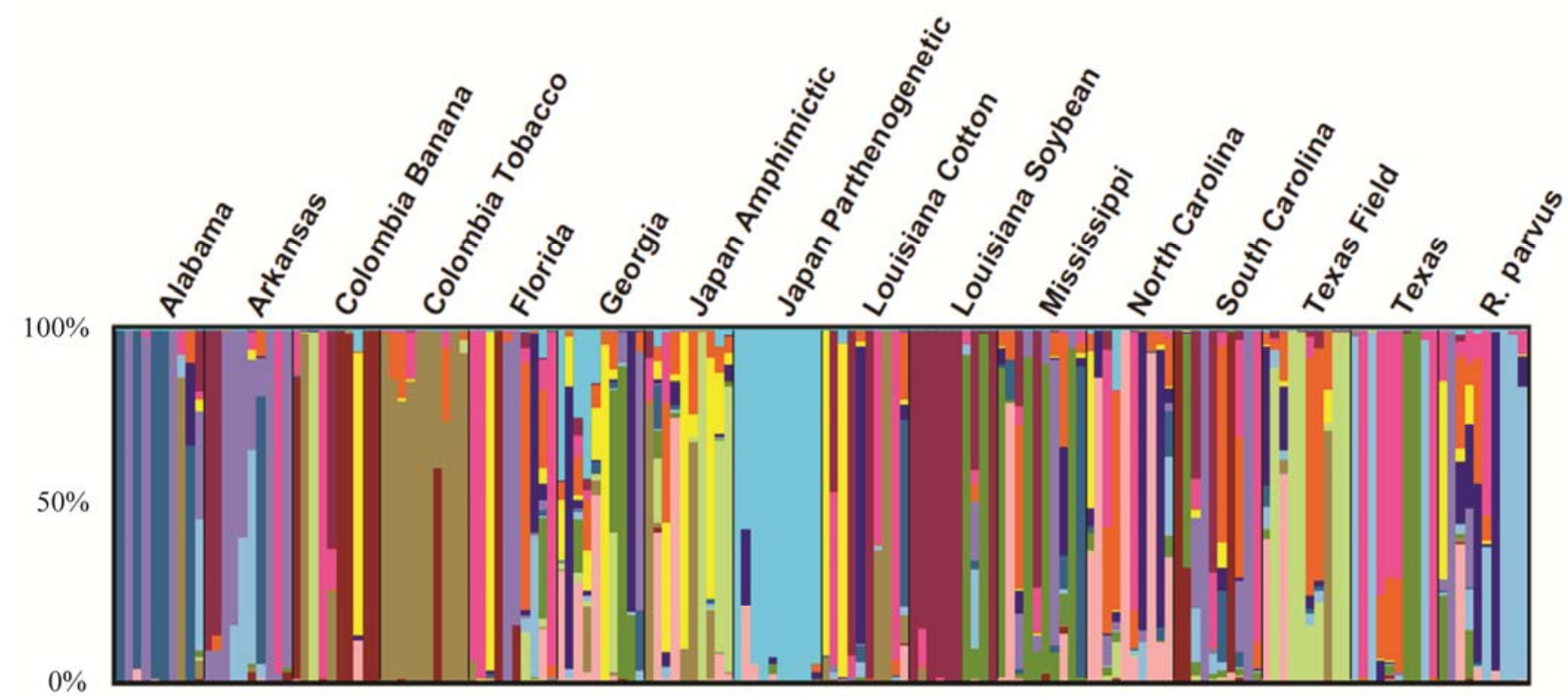

Fig. 2. Graphical representation of haplotype similarity assignments at 10 microsatellite loci for 160 Rotylenchulus individuals at the best fit grouping number, $\mathrm{K}=14$. Each color represents a cluster based on alleles present in an individual's haplotype. Each line represents the haplotype of an individual at 10 microsatellite loci. 
als retrieved from a field (TXF). When comparing $\mathrm{F}_{\mathrm{ST}}$ values, the two isolates were highly differentiated $\left(\mathrm{F}_{\mathrm{ST}}=0.1587\right)$. In contrast, isolates parasitizing different hosts from Colombia and Louisiana did not show population subdivision or genetic differentiation. Both isolates from Colombia and Louisiana were obtained from an infested field and were not cultured in a greenhouse. These observations support the view that isolates maintained in a greenhouse will exhibit differences in genetic diversity when compared to field population.

An excess of homozygotes was observed at all isolation locations, resulting in isolates not conforming to expected HardyWeinberg proportions. The most common cause of homozygote excess is nonrandom mating or the Wahlund effect. The Wahlund effect is often due to population subdivision when two distinct populations are analyzed as one (2). The presence of null alleles can also cause a perceived deficiency of heterozygotes. The presence of null alleles can also cause a perceived deficiency of heterozygotes.

The Wahlund effect is the result of subpopulations having different allele frequencies being studied as one population, but when studied individually, are in Hardy-Weinberg proportions. Our results do not indicate a Wahlund effect occurring on each isolation location. Each isolation location was studied separately, and none were found to be in expected Hardy-Weinberg proportions. Also, the excess of homozygotes observed was not locus specific nor population specific, suggesting that our results were not due to a Wahlund effect but that another factor was causing the excess in homozygotes.

Null alleles are common in genetic studies in DNA markers such as microsatellites $(9,27,29)$. From our results, there is relatively little variance in $\mathrm{F}_{\mathrm{IS}}$ across loci. Also, loci with the highest $\mathrm{F}_{\mathrm{IS}}$ variance were not those with the highest calculated $\mathrm{F}_{\text {IS }}$ (Fig. 3), which would be expected with the presence of null alleles. These results make the null allele explanation unlikely.

Based on $\mathrm{F}_{\mathrm{IS}}$, the excess of homozygotes is most likely due to a high level of inbreeding within isolation locations. Here, $\mathrm{F}_{\mathrm{IS}}$ is the measure of heterozygote deficiency of individuals relative to the subpopulation or isolation location where they were obtained. Due to the relatively limited mobility of Rotylenchulus sp., an excess in homozygotes due to inbreeding is a likely scenario. Brothers and sisters from a single egg mass are likely to procreate due to relatively limited mobility.

An excess of heterozygotes is often expected when studying parthenogenetically reproducing populations such as JP and $R$. parvus and is indicated by a strongly negative $\mathrm{F}_{\mathrm{IS}}$ value (6). Our results did not show an excess in heterozygotes at 10 microsatellite loci for any isolation location. A similar result was observed by Rougeron et al. (36) when studying 124 strains of the protozoan Leishmania braziliensis from four hosts at 12 microsatellite loci. All loci exhibited a positive value for $\mathrm{F}_{\mathrm{IS}}$ even though $L$. braziliensis has historically been considered a clonally reproducing species. The high level of homozygotes may also be an effect of isolates being introduced to the areas where they were collected. Introduced species often exhibit a substantial loss of genetic diversity when they have originated from a small founder population causing a severe founder effect and genetic drift $(3,38)$.

UPGMA cluster analysis and STRUCTURE analysis did not reveal distinct clustering for various reniform nematode isolates due to geographic origin or host resulting in an unresolved phylogenetic analysis (Fig. 1). The high variation present in the Rotylenchulus isolates along with sharing of alleles between isolation locations may explain the unresolved phylogeny. Phylogenetic analysis may not be possible if conflict arises when multilocus data are combined or when multiple mutations have occurred at the same site (22). The individual gene genealogy may have distinct and possibly incompatible evolutionary histories. More microsatellite markers may be needed, or a different type of marker may allow for parsing out of isolates based on isolation location or host.

The high level of variation does not correlate with host or locality, resulting in a wide variety of genetic variability among isolates. A similar result was found for Fusarium poae isolates from Argen-

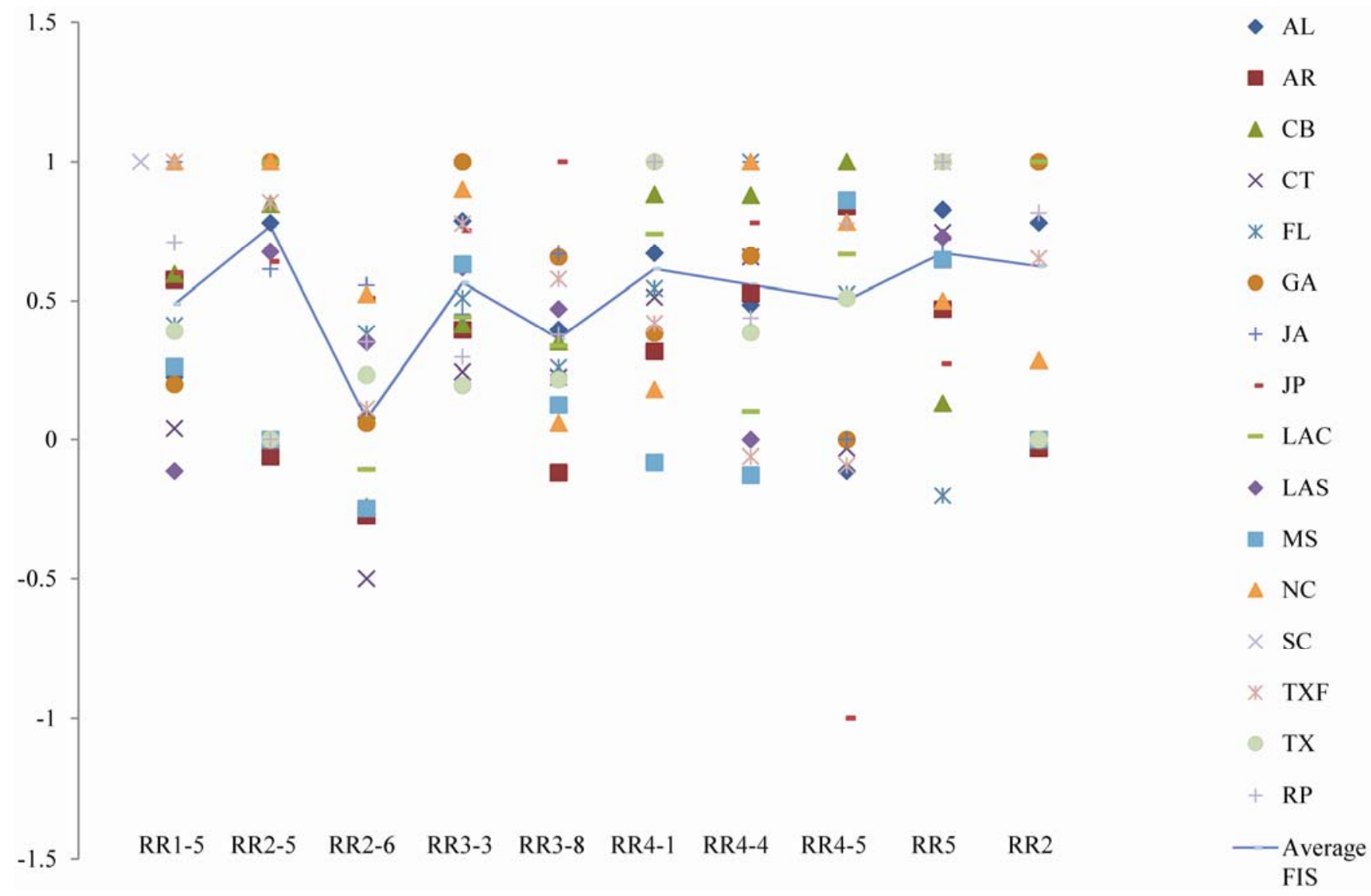

Fig. 3. $F_{\mid S}$ for 10 microsatellite loci in 16 Rotylenchulus populations and average $F_{\mid S}$ for each microsatellite loci. There is a large heterozygote deficiency at each locus. 
tina and England (13) when using inter-simple sequence repeats. Isolates did not show a clear relationship between host or geographic origin, and isolates with the same haplotype were collected from different geographic regions. Maintenance of a high level of genetic variation can indicate the potential for population adaptability. Dennehy et al. (12) showed that a genetically shifting source population can fuel evolution and potential disease emergence. Genetic variation can lead to adaptive potential and increased distribution of a species. We have shown that $R$. reniformis is a highly variable species at 10 microsatellite loci. Characterizing variants could aid management strategies by allowing the ability to monitor changing populations of reniform nematodes that can be correlated to useful traits such as resistance-breaking, increased fitness, or higher virulence.

\section{Literature Cited}

1. Agudelo, P., Robbins, R. T., Stewart, J. M., and Szalanski, A. L. 2005. Intraspecific variability of Rotylenchulus reniformis from cotton-growing regions in the United States. J. Nematol. 37:105-114.

2. Allendorf, F. W., and Luikart, G. 2007. Conservation and the genetics of populations. Blackwell Publishing, Malden, USA.

3. Allendorf, F. W., and Lundquist, L. L. 2003. Introduction: Population biology, evolution, and control of invasive species. Conservation Biol. 17:2430.

4. Arias, R. S., Stetina, S. R., Tonos, J. L., Scheffler, J. A., and Scheffler, B. E. 2009. Microsatellites reveal genetic diversity in Rotylenchulus reniformis populations. J. Nematol. 41:146-156.

5. Baker, A. D. 1962. Check list of the nematode superfamilies Dorylaimoidea, Rhabditoidea, Tylenchoidea, and Aphelenchoidea. E.J. Brill, Leiden, The Netherlands.

6. Balloux, F., Lehmann, L., and de Meeus, T. 2003. The population genetics of clonal and partially clonal diploids. Genetics 164:1635-1644.

7. Blasingame, D., Patel, M. V., Larence, K., Gazaway, W., Olsen, M., Kirkpatrick, T., Monfort, S., Davis, M., Marios, M., Kemerait, B., Colyer, P., Scuimbata, G., Lawrence, G., Wrather, A., Goldberg, N., Koenning, S., Pitts, J. T., Muller, J., Newman, M., Woodward, J., Wheeler, T., and Phipps, P. 2010. 2009 Cotton Disease Loss Estimate Committee Report. Proc. Beltwide Cotton Conf. 1:237-240.

8. Botstein, D., White, R. L., Skolnick, M., and Davis, R. W. 1980. Construction of a genetic-linkage map in man using restriction fragment length polymorphisms. Am. J. Human Genet. 32:314-331.

9. Brookfield, J. 1996. Population genetics. Curr. Biol. 6:354-356.

10. Cook, C. G., Robinson, A. F., and Namken, L. N. 1997. Tolerance to Rotylenchulus reniformis and resistance to Meloidogyne incognita race 3 in high-yielding breeding lines of upland cotton. J. Nematol. 29:322-328.

11. Dasgupta, D. R., Raski, D. J., and Sher, S. A. 1968. A revision of genus Rotylenchulus Linford and Oliveira 1940 (Nematoda - Tylenchidae). Proc. Helminthological Soc. Washington 35:169-172.

12. Dennehy, J. J., Friedenberg, N. A., McBride, R. C., Holt, R. D., and Turner, P. E. 2010. Experimental evidence that source genetic variation drives pathogen emergence. Proc. Royal Soc. B-Biol. Sci. 277:3113-3121.

13. Dinolfo, M. I., Stenglein, S. A., Moreno, M. V., Nicholson, P., Jennings, P., and Salerno, G. L. 2010. ISSR markers detect high genetic variation among Fusarium poae isolates from Argentina and England. Eur. J. Plant Pathol. 127:483-491

14. Excoffier, L., and Lischer, H. E. L. 2010. Arlequin suite ver 3.5: A new series of programs to perform population genetics analyses under Linux and Windows. Mol. Ecol. Resour. 10:564-567.

15. Gaur, H. S., and Perry, R. N. 1991. The biology and control of the plant parasitic nematode Rotylenchulus reniformis. Agric. Zool. Rev. 4:177-212.

16. Germani, G. 1978. Morphological and biometrical characters of 3 West African species of Rotylenchulus Nematoda Tylenchida. Rev. Nematol. $1: 241-250$.

17. Glenn, T. C., and Schable, N. A. 2005. Isolating microsatellite DNA loci. Molecular Evolution: Producing the Biochemical Data, Part B 395:202-222.

18. Hubisz, M. J., Falush, D., Stephens, M., and Pritchard, J. K. 2009. Inferring weak population structure with the assistance of sample group information.
Mol. Ecol. Resour. 9:1322-1332.

19. Jarne, P., and Lagoda, P. J. L. 1996. Microsatellites, from molecules to populations and back. Trends Ecol. Evol. 11:424-429.

20. Leach, M., Agudelo, P., and Gerard, P. 2009. Effect of temperature on the embryogenesis of geographic populations of Rotylenchulus reniformis. J. Nematol. 41:23-27.

21. Leach, M. M., Agudelo, P., and Lawton-Rauh, A. 2010. Ten polymorphic microsatellite loci for reniform nematode, Rotylenchulus reniformis. Mol. Ecol. Resour. 11:418-421.

22. Machado, C. A., and Hey, J. 2003. The causes of phylogenetic conflict in a classic Drosophila species group. Proc. Royal Soc. London Ser. B-Biol. Sci. 270:1193-1202.

23. Miller, M. P. 1997. Tools for population genetic analysis (TFPGA) 1.3: A Windows program for the analysis of allozyme and molecular population genetic data. Distributed by the author.

24. Nakasono, K. 2004. Studies on morphological and physio-ecological variations of the reniform nematode, Rotylenchulus reniformis Linford and Oliveira, 1940 with an emphasis on differential geographical distribution of amphimictic and parthenogenic populations in Japan. J. Nematol. 36:356420.

25. Nakasono, K., and Ichinohe, M. 1967. A Japanese reniform nematode Rotylenchulus nicotiana (Yokoo et Tanaka, 1954) n. comb. (Tylenchida: Hoplolaimidae). Japanese J. Appl. Entomol. Zool. 4:169-176. (In Japanese with English summary.)

26. Nei, M. 1978. Estimation of average heterozygosity and genetic distance from a small number of individuals. Genetics 89:583-590.

27. Paetkau, D., and Strobeck, C. 1995. The molecular-basis and evolutionary history of a microsatellite null allele in bears. Mol. Ecol. 4:519-520.

28. Park, S. D. E. 2001. Trypanotolerance in West African cattle and the population genetic effects of selection, Ph.D. thesis. University of Dublin, Dublin.

29. Pemberton, J. M., Slate, J., Bancroft, D. R., and Barrett, J. A. 1995. Nonamplifying alleles at microsatellite loci - A caution for parentage and population studies. Mol. Ecol. 4:249-252.

30. Pinard, R., de Winter, A., Sarkis, G. J., Gerstein, M. B., Tartaro, K. R., Plant, R. N., Egholm, M., Rothberg, J. M., and Leamon, J. H. 2006. Assessment of whole genome amplification-induced bias through high-throughput, massively parallel whole genome sequencing. BMC Genomics 7:216.

31. Robinson, A. F. 2007. Reniform in US cotton: When, where, why, and some remedies. Annu. Rev. Phytopathol. 45:263-288.

32. Robinson, A. F., Bell, A. A., Dighe, N. D., Menz, M. A., Nichols, P. L., and Stelly, D. M. 2007. Introgression of resistance to nematode Rotylenchulus reniformis into upland cotton (Gossypium hirsutum) from Gossypium longicalyx. Crop Sci. 47:1865-1877.

33. Robinson, A. F., Cook, C. G., and Percival, A. E. 1999. Resistance to Rotylenchulus reniformis and Meloidogyne incognita race 3 in the major cotton cultivars planted since 1950. Crop Sci. 39:850-858.

34. Robinson, A. F., Inserra, R. N., Caswell-Chen, E. P., Vovlas, N., and Troccoli, A. 1997. Rotylenchulus species: Identification, distribution, host ranges, and crop plant resistance. Nematropica 27:127-180.

35. Rosa, R. C. T., Moura, R. M., Pedrosa, E. M. R., and Chaves, A. 2003. Ocorrência de Rotylenchulus reniformis em Cana de acxu'car no Brasil. Nematol. Bras. 27:93-95.

36. Rougeron, V., De Meeus, T., Hide, M., Waleckx, E., Bermudez, H., Arevalo, J., Llanos-Cuentas, A., Dujardin, J. C., De Doncker, S., Le Ray, D., Ayala F. J., and Banuls, A. L. 2009. Extreme inbreeding in Leishmania braziliensis. Proc. Nat. Acad. Sci. USA 106:10224-10229.

37. Rousset, F. 2008. GENEPOP ' 007: A complete re-implementation of the GENEPOP software for Windows and Linux. Mol. Ecol. Resour. 8:103106.

38. Sakai, A. K., Allendorf, F. W., Holt, J. S., Lodge, D. M., Molofsky, J., With, K. A., Baughman, S., Cabin, R. J., Cohen, J. E., Ellstrand, N. C., McCauley, D. E., O'Neil, P., Parker, I. M., Thompson, J. N., and Weller, S. G. 2001 The population biology of invasive species. Annu. Rev. Ecol. Systematics 32:305-332.

39. Usery, S. R., Lawrence, K. S., Lawrence, G. W., and Burmester, C. H. 2005. Evaluation of cotton cultivars for resistance and tolerance to Rotylenchulus reniformis. Nematropica 35:121-133.

40. Yokoo, T., and Tanaka, I. 1954. On the soil nematodes observed in tobacco fields. Kagoshima Tob. Exp. Stn. B9:59-62. 